\title{
YsxC, an essential protein in Staphylococcus aureus crucial for ribosome assembly/stability Elizabeth L Cooper ${ }^{\dagger}$, Jorge García-Lara ${ }^{\dagger}$ and Simon J Foster*
}

Address: Department of Molecular Biology and Microbiology, University of Sheffield, Sheffield S10 2TN, UK

Email: Elizabeth L Cooper - elizabeth_cooper@merck.com; Jorge García-Lara - j.garcia-lara@sheffield.ac.uk; Simon J Foster* - s.foster@sheffield.ac.uk

* Corresponding author †Equal contributors

Published: 18 December 2009

BMC Microbiology 2009, 9:266 doi:10.1 |86/|47|-2/80-9-266

This article is available from: http://www.biomedcentral.com//47|-2/80/9/266

(C) 2009 Cooper et al; licensee BioMed Central Ltd.

This is an Open Access article distributed under the terms of the Creative Commons Attribution License (http://creativecommons.org/licenses/by/2.0), which permits unrestricted use, distribution, and reproduction in any medium, provided the original work is properly cited.
Received: 20 March 2009

Accepted: 18 December 2009

\begin{abstract}
Background: Bacterial growth and division requires a core set of essential proteins, several of which are still of unknown function. They are also attractive targets for the development of new antibiotics. YsxC is a member of a family of GTPases highly conserved across eubacteria with a possible ribosome associated function.

Results: Here, we demonstrate by the creation of a conditional lethal mutant that $y s x C$ is apparently essential for growth in $S$. aureus. To begin to elucidate $Y s \times C$ function, a translational fusion of $Y s \times C$ to the CBP-ProteinA tag in the staphylococcal chromosome was made, enabling Tandem Affinity Purification (TAP) of YsxC-interacting partners. These included the ribosomal proteins S2, SIO and LI7, as well as the ${ }^{\beta \prime}$ subunit of the RNA polymerase. YsXC was then shown to copurify with ribosomes as an accessory protein specifically localizing to the $50 \mathrm{~S}$ subunit. YsxC depletion led to a decrease in the presence of mature ribosomes, indicating a role in ribosome assembly and/or stability in S. aureus.
\end{abstract}

Conclusions: In this study we demonstrate that $Y s \times C$ of $S$. aureus localizes to the ribosomes, is crucial for ribosomal stability and is apparently essential for the life of $S$. aureus.

\section{Background}

Staphylococcus aureus colonises the nares and skin of approximately one-third of the healthy global population [1] and is responsible for a wide variety of infections both in hospitals and the community [2-4]. The increasing antibiotic resistance of $S$. aureus has led to the search for alternative drug targets. Amongst them, proteins indispensable for cellular viability are optimal candidates. There are currently about 15 essential proteins from bacterial genomes used as antibiotic targets encompassing a restricted set of microbial processes, including DNA replication and repair, fatty acid and protein biosynthesis, and cell wall synthesis [5]. A large number of essential proteins remain to be investigated for novel antimicrobial development.

In a genome-wide study in Bacillus subtilis the IPTG-inducible $\mathrm{P}_{\text {spac }}$ conditional expression system was used to determine gene essentiality [6]. A subset of 15 genes identified in this screening had no significant homology to any gene of known function, and included the well-conserved Era/ Obg family of GTP binding proteins [6]. The latter belongs to a diverse superfamily of the often referred to as low molecular weight GTPases, which act as molecular switches in the regulation of crucial cellular processes across all domains of life, including: intracellular and 
membrane signalling, vesicular transport, cell division, chromosome partitioning, protein targeting and ribosomal function [7].

Although very few of the bacterial low molecular weight GTPases have well characterised roles, there is increasing evidence that members of the Era/Obg family of GTPases are involved in ribosome function, assembly or stability. Work on Era, Obg, YjeQ/YloQ, YlqF, YphC, and YsxC in E. coli and B. subtilis has indicated associations of these proteins with ribosomal subunits and changes in ribosomal profiles [8-10]. Ribosome profiles, created by separation of ribosome constituents on a sucrose gradient, show a decrease in whole $70 \mathrm{~S}$ ribosomes with an concomitant increase in $30 \mathrm{~S}$ and $50 \mathrm{~S}$ ribosomal subunits after depletion of the protein of interest [9,11-15].

YsxC in B. subtilis (YihA in E. coli) is an ortholog of the Era/ Obg family of GTP-binding protein that has been reported to be essential in B. subtilis, E. coli, S. pneumoniae, H. influenzae, and M. genitalium $[9,16,17]$. We have previously solved the crystal structure of the B. subtilis YsxC in its open and closed conformations, proven its ability to complex with GDP and GTP, and shown the conformational changes occurring upon nucleotide binding and GTP hydrolysis [18].

A B. subtilis mutant with $y s x C$ under the control of the regulatable $\mathrm{P}_{\text {spank }}$ promoter has revealed that depletion of the protein led to the accumulation of intermediate $50 \mathrm{~S}$ subunits (described as $44.5 \mathrm{~S}$ subunits) different from those seen upon depletion of similar GTPases YphC and YlqF [9]. However, as with YlqF and YphC depletion, intermediates lacked ribosomal proteins L16, L36 and possibly L27. Other putative ribosomal interacting partners of YsxC have been suggested by Wicker-Planquart and coauthors [10]. YsxC is likely to be essential across eubacteria.

In this study we demonstrate that YsxC of $S$. aureus localizes to the ribosomes, is crucial for ribosomal stability and is essential for the life of $S$. aureus.

\section{Results}

\section{YsxC is essential in S. aureus}

To test whether $y s x C$ was essential in $S$. aureus, a strain containing a single chromosomal copy of $y s x C$ under the control of a regulatable promoter $\left(\mathrm{P}_{\text {spac }}\right)$, repressed by LacI and requiring the inducer IPTG for expression was constructed as indicated in Material and Methods (See also Figure 1). Growth of LC109 (SH1000 $\left.\mathrm{P}_{\text {spac }} \sim \gamma s x \mathrm{C} / \mathrm{pGL485}\right)$ at several IPTG concentrations $(0 \mu \mathrm{M}, 5 \mu \mathrm{M}, 10 \mu \mathrm{M}$ and $500 \mu \mathrm{M}$ ) was analysed on BHI agar plates supplemented with chloramphenicol to ensure maintenance of the lacIcontaining plasmid (Figure 2A). Strong growth can be seen on the plate containing $500 \mu \mathrm{M}$ IPTG with distinctive single colonies, which are absent on the plate without IPTG. The phenotype on solid medium was further con-
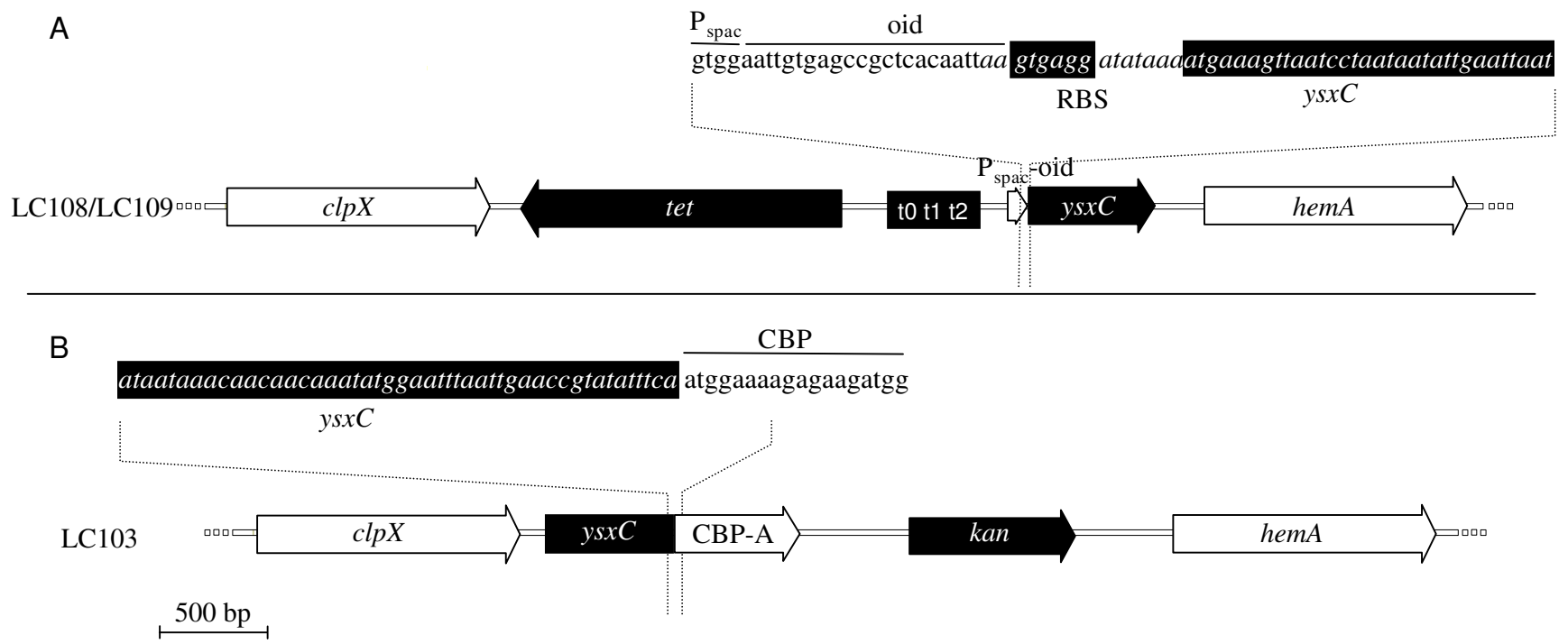

Figure I

Detailed scale representation of the $P_{\text {spac }} \sim y s x C$ (LCI 08/LC I 09) and ysxC::TAP-tag (LCI 03) chromosomal constructs. $\lambda_{\text {red }}$ recombination allowed highly specific chimera construction resulting in the Tet-T-P spac $_{\text {or TAP-tag-kan cassette }}$ insertions. The relevant sequence junctions are shown for both constructs. Chromosomal sequence is shown in italics and relevant features generated by $\lambda_{\text {red }}$ recombination are underlined. 


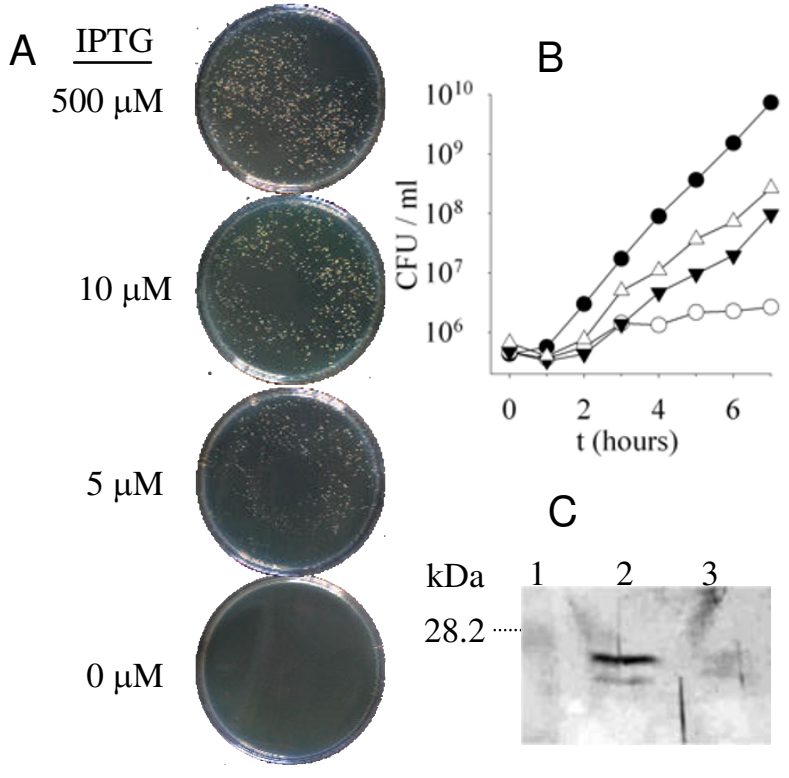

Figure 2

YsxC requirement for $S$. aureus growth. A) Strain LCI09 (SHI000 $\mathrm{P}_{\text {spac }} \sim y s x$ C/pGL485) was grown on BHI agar plates containing $20 \mu \mathrm{g} \mathrm{ml} \mathrm{m}^{-1} \mathrm{Cam}$ and $500 \mu \mathrm{M}, 10 \mu \mathrm{M}, 5 \mu \mathrm{M}$ or $0 \mu \mathrm{M}$ IPTG overnight. B) Exponentially growing cultures of strains SHIOO0 (O) and LCI09 (SHI000 $\mathrm{P}_{\text {spac }} \sim$ ysxCl pGL485) $(\bigcirc, \tau, \rho)$ were washed and resubcultured to approximately $1 \times 10^{6} \mathrm{CFU} \mathrm{ml^{-1 }}$ in $\mathrm{BHI}(0)$ or in $\mathrm{BHI}$ supplemented with $20 \mu \mathrm{g} \mathrm{ml}^{-1}$ Cam plus different concentration of IPTG: 0 (O), $10 \mu \mathrm{M}(\boldsymbol{\nabla})$ or I $\mathrm{mM}(\triangle)$. Growth was monitored as CFU/ml. c) Western blot using anti-YsxC polyclonal antibodies. Strains SHIO00 and LCI09 (SHI000 $\left.\mathrm{P}_{\text {spac }} \sim y s x C / p G L 485\right)$ were grown to an $\mathrm{OD}_{600}=0.5 \mathrm{in} \mathrm{BHI}$ and $\mathrm{BHI}$ plus $20 \mu \mathrm{g} \mathrm{ml}-$ I Cam, respectively. Cells were harvested by centrifugation, the membrane protein fraction extracted and samples were separated by $12 \%$ (w/v) SDS-PAGE. Lane: I, the size of molecular weight markers separated on the same gel is indicated; 2, SHI000; 3, LCI09.

firmed in liquid medium (Figure 2B). In a different experiment it was shown that the presence or absence of IPTG does not affect growth of the wild type SH1000 strain (data not shown), while growth of LC109 (SH1000 $\mathrm{P}_{\text {spac }} \sim y s x$ C/pGL485) is IPTG concentration dependent (Figure 2B). No distinguishable alterations were observed on YsxC-depleted cells under light or transmission electron microscopy (data not shown). The number of viable counts on LC109 incubated in the absence of IPTG remained virtually unchanged, while in the presence of 1 $\mathrm{mM}$ IPTG it increased by 2 logs. Interestingly, even at 1 mM IPTG, LC109 (SH1000 $\mathrm{P}_{\text {spac }} \sim y s x$ C/pGL485) had a growth defect when compared to the wild type SH1000 strain $\left(2.8 \times 10^{8}\right.$ and $7.3 \times 10^{9} \mathrm{CFU}$ after $7 \mathrm{~h}$, respectively). These results demonstrate that $y s x C$ is apparently essential for growth of $S$. aureus in these conditions.
To study if the reduction in growth rate seen using the $y s x C$ conditional lethal strain LC109 (SH1000 $\mathrm{P}_{\mathrm{spac}} \sim \gamma s x \mathrm{C}$ ) pGL485) correlated with a concomitant depletion of YsxC, protein levels after growth without IPTG were analysed. As indicated above, cells showed a severe growth defect when IPTG was lacking, thus limiting the yield for biochemical analysis. To overcome this, a higher initial inoculum $\left(\mathrm{OD}_{600}=0.01\right)$ was used and cultures were grown with choramphenicol and IPTG (with $500 \mu \mathrm{M}$ or without). At this inoculum density, without IPTG the growth rate of LC109 (SH1000 $\mathrm{P}_{\text {spac }} \sim \gamma s x C /$ pGL485) was still approximately 1 log below that of SH1000 after 5 hours of growth (data not shown). Equal amounts of material purified by ultracentrifugation were analysed by SDS-PAGE (data not shown) and Western blotting, probing with anti-YsxC polyclonal antibody (See Methods; Figure $2 \mathrm{C}$ ). In SH1000 there is a major YsxC cross-reactive band of $\sim 26 \mathrm{kD}$ and a minor band of $\sim 25 \mathrm{kD}$, corresponding to a size similar to the predicted molecular weight, i.e., $23 \mathrm{kD}$. Both bands show lower intensity in LC109 (SH1000 $\mathrm{P}_{\text {spac }} \sim y s x C /$ pGL485) grown without IPTG. Hence, $y s x C$ downregulation is accompanied by a decrease in YsxC concentration in the cell.

\section{Purification of $Y_{s x} C$ interacting partners}

One method used to elucidate the function of a protein of interest is to search for protein partners with which it interacts in the cell. In order to identify proteins interacting with YsxC, the protein was TAP-tagged [strain LC103 (SH1000 spa::tet $\gamma s x C:: T A P)]$ and an interactive complex purified as described in Materials and Methods. The resulting proteins were separated by SDS PAGE and silver stained (Figure 3). 16 distinctive protein bands found in the eluted YsxC complex were trypsin digested and the amino acid sequence of the resulting fragments determined by mass spectrometry. Subsequently, a MASCOT search for proteins in the database containing these sequences was carried out. Table 1 shows the most probable identity of each of the bands as per its Mowse score. 10 of the 16 bands were identified as proteins from S. aureus, one band was not identified, and four of them (casein and keratin) corresponded to preparation contaminants.

The band that had the highest probability of a match was Band 13. Its Mowse score for $30 \mathrm{~S}$ ribosomal protein S5 was 246 with a threshold level of 38 . Since 5 fragments from this band matched to this protein the identification is highly probable. Other bands with high match identities were Band 5 (aerobic glycerol-3-phosphate dehydrogenase), Band 8 ( $30 \mathrm{~S}$ ribosomal protein S2), Band 15 (50 $\mathrm{S}$ ribosomal protein L17) and Band 16 (30 S ribosomal protein S10) (Table 1). YsxC, the protein originally tagged, was also identified as a high match band (Band 9, 227(36)). All these proteins matched at least 2 fragments from the band. For 2 parent ions with a score of $95 \%$ or 


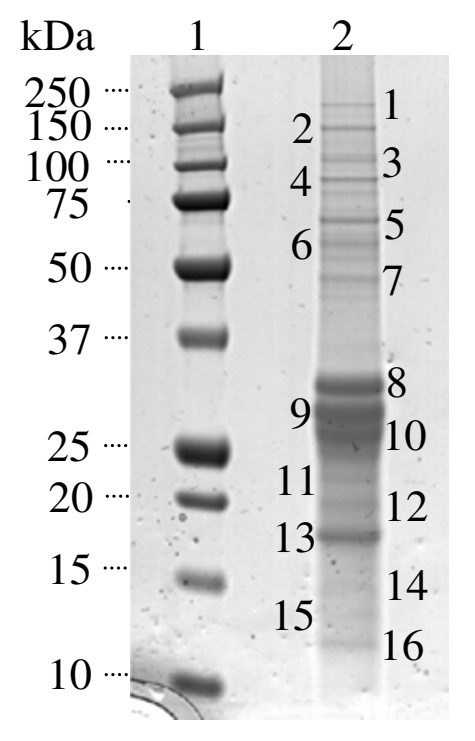

Figure 3

Identification of YsxC interacting proteins. Proteins were separated on a 4-12\% (w/v) SDS-PAGE gradient gel and silver stained. Lane: I, molecular mass markers of sizes shown; 2, YsxC complex proteins from I 5 I of original culture. The band numbers correspond to those that were analysed by mass spectrometry.

better, one can assume that the proteins has been identified.

Other interacting bands identified with a score indicative of extensive homology (i.e., 36, See Methods) were bands 2 and 7, and corresponded to the DNA-directed RNA polymerase beta' chain protein and putative elongation factor Tu. However, although the former matched 2 fragments, the latter, like SecA and PflB, were one hit matches, which would require further validation to be considered as legitimate YsxC partners. Similarly, Bands 3 and 4 corresponded to casein, a protein not present in $S$. aureus but a common preparation contaminant.

TAP tagging has not previously been reported in S. aureus therefore it was important to eliminate the possibility that any of the proteins identified, corresponded to purification artefacts. An independent purification of an unrelated TAP-tagged protein of $S$. aureus most likely participating in phospholipid metabolism and also purifying with the membrane fraction was carried out (YneS/ PlsY; García-Lara and Foster, unpublished). It revealed interactions with proteins also encountered in our search for YsxC partners: 30 S ribosomal protein S5, elongation factor $\mathrm{Tu}$ and aerobic glycerol-3-phosphate dehydrogenase (data not shown). Although these data do not exclude the corresponding proteins as legitimate interact- ing partners of YsxC and YneS/PlsY, the involvement of these two proteins in different aspects of bacterial physiology suggests the common partners as likely artefacts of the purification procedure. Overall, the protein partners resulting from our experiments suggest YsxC as a ribosome-interacting protein.

\section{Subcellular localisation of YsxC}

The TAP tagging experiment identified several ribosomeassociated proteins as YsxC interacting partners. To examine the putative association of YsxC with ribosomes, a copurification experiment was carried out. Staphylococcal ribosomes were extracted from other cellular materials by several ultracentrifugation and washing steps, and core ribosomes were depleted of accessory ribosomal proteins by ammonium chloride extraction. Equivalent samples from different stages of the purification process were separated by SDS-PAGE, Western blotted and immunodetected with anti-YsxC antibodies (Figure 4). YsxC is in the insoluble fraction following the initial ultracentrifugation of a total cell extract (lane 3 ) and remains in the insoluble fraction after solubilisation of the membranes with Triton X-100 (lane 5). When this insoluble fraction was resuspended in $1 \mathrm{M} \mathrm{NH}_{4} \mathrm{Cl}$, YsxC was solubilised (lane 6). These results suggest that YsxC is associated with the ribosome but is not a core ribosomal protein.

\section{Association of $Y_{s x} C$ with specific ribosomal subunits}

In order to elucidate the nature of the YsxC-ribosome association, material from S. aureus SH1000 containing ribosomes was separated by ultracentrifugation in a sucrose gradient. This separates the ribosome into its constituents, i.e., $30 \mathrm{~S}$ and $50 \mathrm{~S}$ subunits, as well as the whole $70 \mathrm{~S}$ ribosome. The association of YsxC with a particular ribosomal fraction was determined by Western blot immunodetection with anti-YsxC antibodies. As shown in Figure 5 the extract contained the three expected ribosomal fractions and YsxC was primarily located in samples 8-14 corresponding to the $50 \mathrm{~S}$ subunit.

\section{Role of YsxC in the ribosome}

YsxC may play a role in ribosome assembly, activity or stability. Ribosome profiles of wild type and YsxC-depleted cultures were compared. Cells from both cultures were broken in the presence of two different buffers: Ribosome (associating) buffer and S (dissociating) buffer. Ribosome buffer gives conditions where tightly coupled ribosomes will remain intact whereas loosely coupled ribosomes will dissociate into subunits ([19]; Figure 6A, C). In S buffer, the magnesium levels are reduced and the monovalent ions increased which leads to full dissociation of the ribosomes ([20]; Figure 6B, D). After breakage, samples were ultracentrifuged and the pellet containing the ribosomes resuspended and loaded onto $10-30 \%$ (w/v) sucrose gradients in the relevant buffer and centrifuged. $1 \mathrm{ml} \mathrm{sam-}$ 
Table I: MASCOT search results for $Y_{s x C}$ partners

\begin{tabular}{|c|c|c|c|c|}
\hline Band no. & Gene name & Protein & Mowse score (threshold level) * & No. of fragments \\
\hline 1 & not identified & & & \\
\hline 2 & rpoc & DNA-directed RNA polymerase beta' chain & $40(36)$ & 2 \\
\hline 3 & $\sec A$ & preprotein translocase sec $\mathrm{A}$ subunit & $20(35)$ & 1 \\
\hline 4 & pflB & formate acetyltransferase & $27(36)$ & 1 \\
\hline 5 & $g \mid p D$ & aerobic glycerol-3-phosphate dehydrogenase & $167(37)$ & 6 \\
\hline 6 & Casein & & & \\
\hline 7 & tuf & putative elongation factor $\mathrm{Tu}$ & $39(36)$ & I \\
\hline 8 & rpsB & 30 S ribosomal protein $S 2$ & $12 \mid(36)$ & 3 \\
\hline 9 & $y s x C$ & putative GTP-binding protein & $227(36)$ & 2 \\
\hline 10 & Keratin & & & \\
\hline 11 & Casein & & & \\
\hline 12 & Casein & & & \\
\hline 13 & $r p s E$ & $30 \mathrm{~S}$ ribosomal protein $\mathrm{S} 5$ & $246(38)$ & 5 \\
\hline 14 & Casein & & & \\
\hline 15 & $r p l Q$ & 50 S ribosomal protein LI7 & $98(4 I)$ & 3 \\
\hline 16 & rpsj & 30 S ribosomal protein SIO & $173(39)$ & 3 \\
\hline
\end{tabular}

1 Mowse score $=-10 * \log (\mathrm{P})$, where $\mathrm{P}$ is the probability that the observed match is a random event. The higher the number, the better the match. Individual ions with scores greater than the threshold level (in brackets) indicates identity or extensive homology $(p<0.05)$.

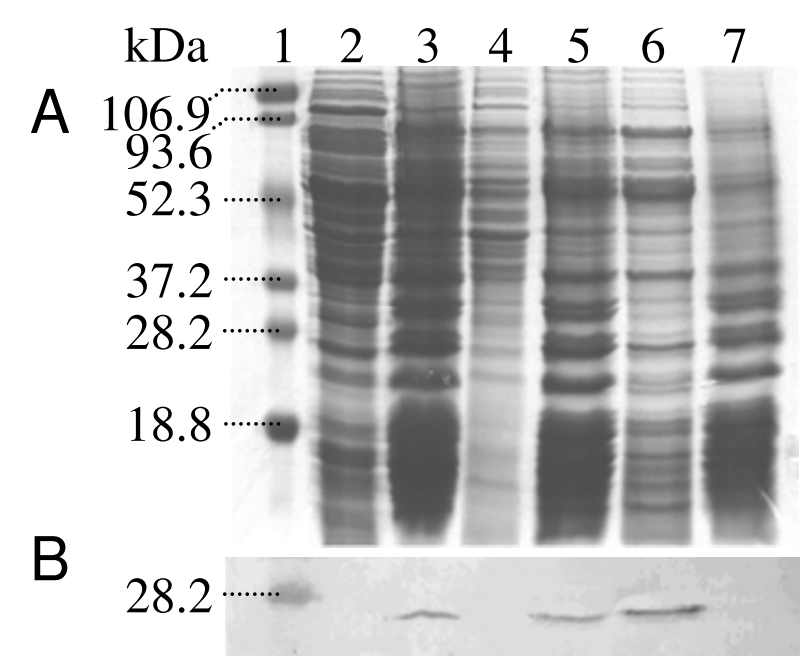

\section{Figure 4}

Subcellular localisation of YsxC. The ribosome-containing fraction of $\mathrm{S}$. aureus $\mathrm{SHI} 000$ was made by ultracentrifugation after cell breakage and removal of cellular debris. Lane: I, pre-stained molecular mass markers; 2, supernatant after ultracentrifugation; 3 , pellet resuspended in buffer, containing $0.5 \%(\mathrm{v} / \mathrm{v})$ Triton $\mathrm{X}-100$, equal to that of the original suspension; 4 , supernatant after the ultracentrifugation step was repeated; 5 , pellet resuspended in buffer containing I $M$ ammonium chloride $\left(\mathrm{NH}_{4} \mathrm{Cl}\right) ; 6$, supernatant after further ultracentrifugation; 7 , pellet resuspended in an equal amount of buffer containing I $\mathrm{M} \mathrm{NH}_{4} \mathrm{Cl}$. Samples were resolved by I2\% (w/v) SDS-PAGE and A) Coomassie Blue stained, or B) Western blotted with antibodies against YsxC. Each lane contains the equivalent of $\mathrm{I} \mathrm{ml}$ of original culture. ples were taken from the base of the gradient and tested for RNA levels (Figure 6).

The ribosome profile of the YsxC-depleted strain (LC109 grown in the absence of IPTG) in associating buffer (Figure 6C) shows a change in ratio of subunits (50 S and 30 $\mathrm{S})$ to whole $(70 \mathrm{~S})$ ribosomes when compared to wild type (Figure 6A). The $30 \mathrm{~S}$ and $50 \mathrm{~S}$ peaks in the depleted strain were larger than that of the $70 \mathrm{~S}$. In contrast, the wild type profile reveals a much larger peak for the whole ribosome than for either of the two subunits. When the ribosome is

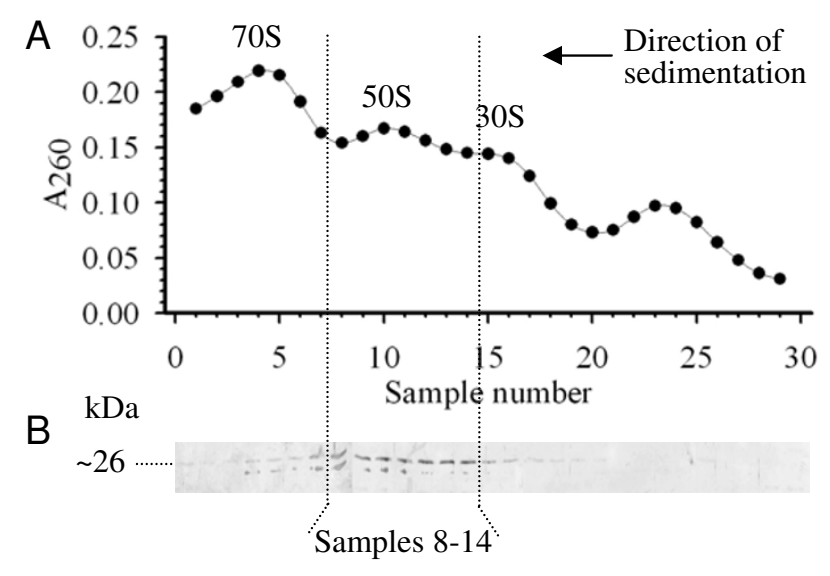

Figure 5

Association of $\mathbf{Y s x} \mathbf{C}$ with ribosomal subunits. A) $A_{260}$ of a ribosome containing fraction of $S$. aureus $\mathrm{SHIOOO} \mathrm{sepa-}$ rated by a $10-30 \%(\mathrm{w} / \mathrm{v})$ sucrose gradient centrifugation. I $\mathrm{ml}$ samples were taken and analysed for RNA content $\left(A_{260}\right)$. B) Western blot of gradient samples probed with anti-YsxC. 


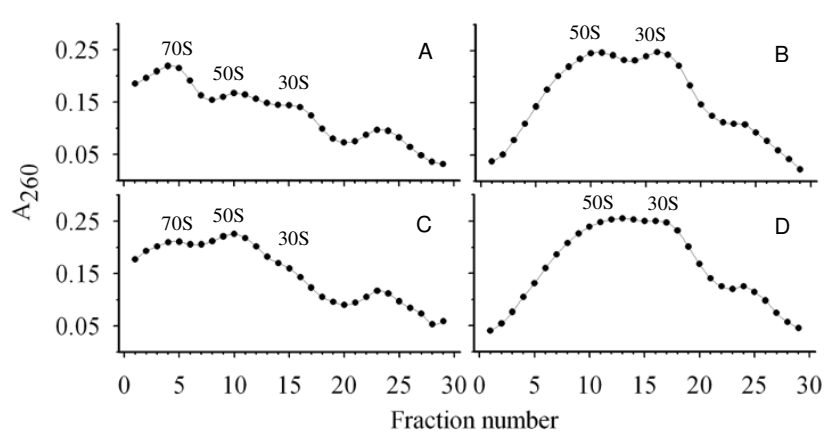

Figure 6

Role of YsxC in ribosomal profile determination. Sucrose gradient profiles were established for extracts from SHIO00 (A, B) and LCI09 (SHI000 $\mathrm{P}_{\text {spac }} \sim$ ysxC/pGL485) grown with no IPTG (C, D). 10-30\% (w/v) sucrose gradients were run in either associating $(A, C)$ or dissociating $(B, D)$ buffers and ribosomes analysed by $A_{260}$ levels in gradient samples.

fully dissociated into its constituent subunits (in S buffer) the levels in wild type and LC109 (SH1000 $\mathrm{P}_{\text {spac }} \sim \gamma s x \mathrm{C}$ ) pGL485) are virtually identical (Figure 6B, D). However the peak for the $50 \mathrm{~S}$ subunits is slightly broader than in the wild type potentially indicating the presence of aberrant $50 \mathrm{~S}$ subunits.

\section{Discussion}

Conditional lethal constructs based on the replacement of the cognate promoters of chromosomal genes by promoters that can be exogenously controlled have been used successfully to identify essential genes in several organisms. For instance, the $\mathrm{P}_{\text {spac }}$ promoter was used in the comprehensive genome wide study of $B$. subtilis, where $y s x C$ was proven to be indispensable [6]. Identification of essential genes in $S$. aureus has also taken advantage of this system and a number of them have been identified including genes involved in cell wall biosynthesis $[21,22]$, a glycoprotease [23] and a two-component system [24]. In this study, we have engineered the chromosomal copy of $S$. aureus $y s x C$ under the control of $\mathrm{P}_{\text {spac }}$. Growth of LC109 (SH1000 $\mathrm{P}_{\text {spac }} \sim \gamma s x C /$ pGL485) depended on the presence of the inducer IPTG in the medium, thereby proving that $y s x C$ is apparently essential in $S$. aureus. Our results are in agreement with data from an antisense study by Forsyth and co-workers suggesting the essentiality of $y s x C$ in $S$. aureus [25]. In the absence of inducer, the strain is unable to form single colonies on plate and only residual growth is detected in liquid medium. The latter is most likely due to the YsxC remaining in the cell at the time of inducer removal and/or the minor leaky nature of $\mathrm{P}_{\text {spac }}$ also observed in the $P_{\text {spank }}$ expression of $y s x C$ by Schaefer and co-workers [9]. Interestingly, even maximum IPTG concentrations are unable to restore the growth rate of the mutant to the SH1000 wild type values. Thus, YsxC could potentially be an interesting target for novel drug development.

Galperin and Koonin cite YsxC in the top 10 list of 'known unknowns' of highly attractive targets for experimental study of conserved hypothetical proteins in S. aureus [26]. Nevertheless, it is extremely important to verify essentiality and analyse gene function in relevant pathogens as not all genes essential in one species maybe so in another.

Tandem affinity purification was originally developed in yeast [27] and has been extensively used in other organisms [28-31], however, not previously in $S$. aureus. TAP tagging of YsxC and subsequent purification indicated interactions with a number of proteins, the majority of which had functions related to or were integral parts of the ribosome. These were $30 \mathrm{~S}$ ribosomal proteins S2 and $\mathrm{S} 10$, and $50 \mathrm{~S}$ ribosomal protein L17. This indicates that the function of YsxC is likely to be related to the ribosome. However, the ribosome is a complex structure and a large number of processes are required for its correct function, including the construction of subunits from ribosomal proteins and RNA and the assembly of the subunits into the whole ribosome before the translation process. Much of the exact details of these processes and which additional factors are required are unknown. S2 and S10 are not located together on the assembled ribosome but involved in the later stages of $30 \mathrm{~S}$ assembly [32]. In contrast, $50 \mathrm{~S}$ ribosomal protein L17, which is localized on the surface of the subunit, binds to 23S rRNA, and even after extensive treatment to dissociate proteins can be found in the core of the $50 \mathrm{~S}$ subunit [33-35]. Importantly, B. subtilis L17 over-expression in E. coli results in abnormal cell division and nucleoid segregation becoming ultimately lethal [36]. Similarly, in B. subtilis, a mutation altering L17 was reported to cause temperature sensitivity and a sporulation defect [37]. Interestingly, depletion of YsxC in B. subtilis results in cell elongation, abnormal cell curvature and nucleoid condensation [38]. Similarly, depletion of YihA in E. coli also impairs cell division [16]. Importantly, deficiency of other small molecular weight GTPases in various species, including ObgE in E. coli, and Bex in B. subtilis also appear to affect cytokinesis and chromosome partitioning [39,40]. Whether these phenotypes are due to the absence of YsxC (and/or L17) or other P-loop GTPases directly impinging on the cell division-related apparatus or a downstream pleiotropic effect remains to be studied. Our light and transmission electron microscopy studies of the cellular morphology of $S$. aureus YsxC-depleted cultures did not reveal a conspicuous deviation from that wild type cells (data not shown).

Recent reports based on the ribosomal intermediates accumulated following YsxC depletion or Far-Western blotting analysis of purified ribosomal proteins have sug- 
gested other YsxC interacting partners in E. coli and/or $B$. subtilis. A few are essential for viability (L6, L7/L12, L10, L23, and perhaps L16) while others, although required for optimal growth, are dispensable (L1, L27 and L36) [9,10]. The L7/L12 stalk (which binds L10 at its base) has been suggested to participate in 23S RNA binding and on the recruitment of peripheral ribosomal factors [41]. Structural studies on the topology of several proteins including L7/12, L1, L6 and S5 has led to postulate a role for them as RNA binders probably stabilizing rRNA tertiary structure by fixing the positions of pairs of rRNA sequences [42]. The possible YsxC contribution to, RNA stabilization remains to be determined. Although the bulk of L7/L12 resides within the $50 \mathrm{~S}$ region, evidence of its interaction with the 30 S subunit, including S2 has been provided by cross-linking studies (See Review [43]). In addition, immuno-EM observations provide supportive evidence for different locations within the ribosome for the L7/L12 carboxy-terminal end including the $30 \mathrm{~S}$ subunit. It is also worth noting that most of the proteins shown to interact with YsxC are well exposed on the surface of the E. coli ribosome: S1 (which requires S2 for binding to the $30 \mathrm{~S}$ subunit), S5, L7/L12, L10, L17 [44]. Thus providing clues as to the location of YsxC within the ribosome.

Butland and co-authors found YihA (the E. coli YsxC homolog) to associate with itself [28]. In our study such interaction would not be detectable as only the tagged copy of the $y s x C$ was present in the chromosome. However, our experimental design enabled us to confirm that the YsxC-TAP-tag protein was functional, excluding the possibility of inactive protein artefacts.

The interaction we have observed between YsxC and the $\beta^{\prime}$ subunit of RNA polymerase, has also been previously reported for ObgE $[14,28]$. Further work needs to be done to first confirm this interaction in $S$. aureus and then establish whether it relates to ribosomal or extra-ribosomal functions as reported for L24 of B. subtilis [45].

P-loop GTPases, such as YsxC, show an association mainly with one or other subunit of the ribosome. For instance, Era and YjeQ with the $30 \mathrm{~S}$ subunit $[46,47]$, and Obg, YlqF and YphC with the $50 \mathrm{~S}$ subunit $[9,13,48]$. We have shown here that YsxC also associates with the $50 \mathrm{~S}$ subunit, a similar behaviour to its ortholog in B. subtilis [10]. Since our co-fractionation experiments revealed the interaction of YsxC with proteins from the small and large ribosome subunits, its absence from the $30 \mathrm{~S}$ fraction could be due to lower affinity and/or stability of YsxC towards its partners in that subunit. The specific role of YsxC and other P-loop GTPases in the assembly or stability of the $50 \mathrm{~S}$ subunit remains to be determined.

After YsxC depletion, the amount of $70 \mathrm{~S}$ ribosome decreases with concomitant subunit increase. This could be due to an error in the assembly of the subunits themselves or their assembly into the whole ribosome. As the levels of individual subunits after full dissociation stays approximately the same between wild type and YsxC depleted cells it is possible that the subunits are not being fully assembled. This was observed in B. subtilis where depletion of YsxC results in a number of proteins missing from the $50 \mathrm{~S}$ subunit, ultimately resulting in the accumulation of aberrant large subunits [10]. It has been reported by these authors that YsxC in B. subtilis binds the $44.5 \mathrm{~S}$ preribosomal particle. The depletion conditions used to enable the harvesting of sufficient biomass for ribosomal extraction required some growth of the culture, prior to cessation, which could have partially masked the presence of distinctive intermediates.

YsxC could also act at the level of ribosomal stability; once the ribosome is assembled it may require transient external proteins for stabilization, as it has been postulated for Era [49]. This could explain the interaction of ObgE, one of the P-loop GTPases, with both of the ribosomal subunits observed by Sato and co-workers in E. coli [14]. The dual interaction could be mediated by the presence of ribosomal constitutents modulating YsxC GTPase activity, by GTPases activating proteins (GAPs) or guanine exchange factors (GEFs) [50], or the intracellular guanine pool [51]. However, additional evidence of ObgE association with the small ribosomal particle is needed since other authors have only reported the co-fractionation of Obg homologs with the $50 \mathrm{~S}$ fraction in E. coli and other species $[48,52,53]$.

\section{Conclusions}

In this article we have successfully used conditional lethal genetic constructs and implemented Tandem Affinity Purification technology in S. aureus to show that YsxC in $S$. aureus is an apparently essential protein that associates with the large ribosomal subunit and plays a role in ribosomal assembly or ribosomal stability. Ribosomal components have been a proven target for successful antibiotics, the elucidation of the role of additional essential and highly conserved ribosomal proteins such as YsxC would open a new avenue to the discovery of novel antimicrobial drugs.

\section{Methods}

\section{Media and growth conditions}

Strains and plasmids are listed in Table 2. E. coli was grown in Luria-Bertani (LB) medium and $S$. aureus in $\mathrm{BHI}$ (Oxoid). Growth was carried out at $37^{\circ} \mathrm{C}$, with shaking at $250 \mathrm{rpm}$ for liquid media. To verify essentiality, cultures were inoculated to $\mathrm{OD}_{600} \sim 0.0001$. When required, antibiotics were added at the following concentrations: ampicillin (Amp), $100 \mathrm{mg} \mathrm{l}^{-1}$; chloramphenicol (Cam), $20 \mathrm{mg} \mathrm{l}^{-}$ 1; erythromycin (Ery), $5 \mathrm{mg} \mathrm{l}^{-1}$; lincomycin (Lin), $25 \mathrm{mg} \mathrm{l}^{-}$ 1; kanamycin (Kan), $50 \mathrm{mg} \mathrm{l}^{-1}$ and neomycin (Neo), 50 
$\mathrm{mg} \mathrm{l}^{-1}$; tetracycline (Tet), $5 \mathrm{mg} \mathrm{l}^{-1}$. Selection of $S$. aureus strains containing the ery or kan genes was made on Ery/ Lin and Kan/Neo, respectively. The $S$. aureus NCTC8325 (SH1000 parental strain) gene homolog of the B. subtilis $y s x C$ is SAOUHSC0177.

\section{Construction of S. aureus SHIOOO containing a chromosomal single copy of ysx $\mathrm{C}$ under the control of a regulatable promoter}

Oligonucleotide primers used are listed in Table 3 and a map of the final chromosomal construct is shown in Figure 1A. pELC6 was created by cloning the Tet-T-P $\mathrm{spac}_{\text {cas- }}$ sette from pGL400 into a vector containing the $y s x C$ gene region from S. aureus SH1000 (pGL411). pGL400 was constructed in a 3-way ligation reaction into the HindIII site of pOB [54] of the following PCR-amplified fragments: a) the tet resistance gene from plasmid pDG1513 [55] (670 bp fragment; primers: 5'GLUSh6B1 and 3'GLUSh6B); and, b) a 2236 bp fragment (primers: 5'GLUSh6A1 and 3'GLUSh6A) from pMUTIN [56] containing the tot $1 \mathrm{t} 2$ transcriptional terminators, the $\mathrm{P}_{\mathrm{spac}}$ promoter and the oid regulatory region. pGL411 is a pOB derivative containing the $S$. aureus $y s x C$ region including 1397 bp upstream and 1354 bp downstream of this gene which was produced using primers 5'GLUSh3I and 3'GLUSh3I. The Tet-T-P ${ }_{\text {spac }}$ cassette was amplified from pGL400 using primers 5'GLUSh16H and 3'GLUSh16H and inserted upstream of $y s x C$ in pGL411 (strain E. coli GL1299) by $\lambda$ red recombination [57]. The resulting plasmid was named pELC6. Purified pELC6 was electroporated into $S$. aureus RN4220 [58] to create, by suicidal recombination, an intermediate strain (LC107) containing two copies of $y s x C$ : a wild type and a $P_{\text {spac }} \sim y s x C$. Using $\phi 11$ phage transduction [59] from LC107 into SH1000 the resident $y s x C$ gene in $\mathrm{SH} 1000$ was replaced by a single copy of $y s x C$ under the control of $\mathrm{P}_{\text {spac }}$ by selecting for transductants resistant to tetracycline and sensitive to erythromycin. The resulting strain was named LC108 (SH1000 $\mathrm{P}_{\text {spac }} \sim y s x C$ ). Replacement was confirmed by Southern blot analysis (results not shown). A multicopy plasmid containing lacI was constructed (pGL485) and transduced into LC108 to generate LC109 (SH1000 $\left.\mathrm{P}_{\text {spac }} \sim y s x C / p G L 485\right)$. pGL485 is a pMJ8426 [21] derivative where the tetracycline resistance gene between the ClaI and SalI sites has been replaced by the chloramphenicol acetyl transferase gene (cat) from pSK5630 [60]. The latter fragment was obtained by PCR amplification using primers, 5'GLUSh103A and 3'GLUSh103A.

\section{Construction of an in vivo YsxC-Tandem Affinity Purification (TAP) tagged construct in S. aureus}

A plasmid containing the TAP-tag cassette (pGL433) linked to kanamycin resistance was constructed as follows. Two PCR-amplified fragments (ReadyMix ABgene) were ligated together at the NotI site: a) a fragment from
pBS1479 [27] containing the Calmodulin Binding Protein (CBP)/Protein A tag (TAP-tag cassette) [30]; and, b) the kanamycin resistance gene from Streptococcus faecalis (kan) present in plasmid pMAL7 [61]. The resulting TAP-tag-kan cassette fragment was cloned in the A-overhang site of pCRII TOPO (Invitrogen) to give pGL433. The TAP-tagkan cassette was PCR-amplified from pGL433 and inserted into pGL411 (in strain E. coli GL1299) by $\lambda$ red recombination as a TAP-tag translational fusion to $y s x C$ (plasmid pELC1). The resulting $y s x C::$ TAP-tag-kan fragment was flanked by the chromosomal upstream (1397 bp) and downstream (1354 bp) regions surrounding $y s x C$ present in pGL411. pELC1 was electroporated into $S$. aureus $\mathrm{RN} 4220$, which generated by single cross-over suicidal recombination a strain with two copies of $y s x C$, one wild type and one TAP-tagged, LC101. A strain was constructed with the Protein A-encoding gene ( $s p a)$ deleted. $S$. aureus 8325-4 spa::tet [62] was lysed with $\phi 11$ and the spa mutation transduced into SH1000 to give LC102 (SH1000 spa::tet). Resolution of the two copies of $y s x C$ in LC101 into only a $y s x C::$ TAP-tagged copy was achieved by $\rho$ 11-mediated transduction [59] of a LC101 lysate into LC102. Transductants resistant to kanamycin ( $y s x C:$ TAPtag) and tetracycline (spa::tet) but sensitive to erythromycin (antibiotic marker linked to the wild type copy of $y s x C$ in pELC1) would have only $y s x C \sim T A P$-tag in a spa-background, LC103 (SH1000 spa::tet ysxC::TAP-tag-kan). This strain was verified by Southern blot analysis (results not shown). Figure 1B shows the final chromosomal insertion, with the relevant DNA junction sequence.

\section{Tandem affinity purification}

Cultures of LC103 were grown in BHI to mid-exponential phase $\left(\mathrm{OD}_{600} \sim 3.0\right)$, placed immediately onto ice slurry for $10 \mathrm{~min}$, harvested by centrifugation $(6,000 \mathrm{rpm}, 10$ $\min , 4^{\circ} \mathrm{C}$, Jouan CR3i rotor AC50.10), frozen in liquid nitrogen and stored at $-80^{\circ} \mathrm{C}$. Subsequently, a cell extract was obtained from cells broken with a Braun homogeniser. The fraction containing membranes and ribosomes was isolated by centrifugation at 50,000 rpm for $2.5 \mathrm{~h}$ in a Beckman 70.1 Ti rotor. This fraction was subsequently purified using a method based on that previously reported by Puig et al. (2001) [27]. All binding and elution steps were performed in $0.8 \times 4 \mathrm{~cm}$ Poly-prep columns (BioRad). $200 \mu$ of IgG-Sepharose bead suspension (Amersham Biosciences) was transferred into the column and the beads were washed with $10 \mathrm{ml}$ IPP150 (10 mM Tris$\mathrm{HCl} \mathrm{pH} 8.0,150 \mathrm{mM} \mathrm{NaCl}, 0.1 \% \mathrm{v} / \mathrm{v}$ Nonidet NP-40). 10 $\mathrm{ml}$ of extract in IPP150, corresponding to $2.5 \mathrm{l}$ of original culture, was transferred into the column, sealed and rotated for $4 \mathrm{~h}$ at $4{ }^{\circ} \mathrm{C}$ to allow binding of Protein $A$ to the resin. Multiple purifications were run in parallel to increase protein yield. Elution to remove unbound protein was performed by gravity flow washing the beads three times with $10 \mathrm{ml}$ IPP150 supplemented with Noni- 
Table 2: Strains and plasmids used in this study

\begin{tabular}{|c|c|c|}
\hline Strain & Relevant genotype/markers & Source \\
\hline \multicolumn{3}{|l|}{ Escherichia coli } \\
\hline EL250 & $\begin{array}{l}\text { F- } m c r \Delta(m r r-h s d R M S-m c r B C) \varphi 80 \text { lacZ } \Delta \text { MI5 } \Delta \text { lac } \times 74 \text { recA I deoR araD I } 39 \Delta \text { (ara-leu) } 7697 \text { galU galK } \\
\text { rpsL (StrR) endAI nupG }[\lambda c \mid 857 \text { araC-PBADflpe] }\end{array}$ & [57] \\
\hline GLI299 & EL250/pGL4II & This study \\
\hline $\begin{array}{l}\text { TunerTM(DE3) pLacl } \\
\text { Staphylococcus aureus }\end{array}$ & F- ompT hsdSB(rB- mB-) gal dcm lacYl (DE3) pLacl (Cam) & Novagen \\
\hline LCIOI & RN4220 ysxC::TAP-tag & This study \\
\hline LCIO2 & $\mathrm{SHIOOO} \mathrm{spa}$ & This study \\
\hline LCIO3 & SHI000 spa ysxC::TAP-tag & This study \\
\hline LCIO7 & $\mathrm{RN} 4220 \mathrm{P}_{\text {spac }} \sim y s x \mathrm{C} y s x \mathrm{C}+$ & This study \\
\hline LCI08 & $\mathrm{SHI} 000 \mathrm{P}_{\mathrm{spac}}^{\mathrm{spac}} \sim \mathrm{ys} x \mathrm{C}$ ys $x \mathrm{C}+$ & This study \\
\hline LCI09 & $\mathrm{SHI} 000 \mathrm{P}_{\text {spac }} \sim y s \times C$ ysxC+/pGL485 & This study \\
\hline RN4220 & Restriction deficient transformation recipient & [58] \\
\hline SHIOOO & Functional rsbU+ derivative of $8325-4$ & [63] \\
\hline SJF590 & 8325-4 spa::tet & [62] \\
\hline Plasmid & Relevant genotype & Source \\
\hline pBSI479 & CBP/Protein A tag & {$[27]$} \\
\hline pDG I5I3 & Tetracycline resistance gene (tet) & [55] \\
\hline pELCl & PGL4II derivative with TAP-kan cassette in frame with $3^{\prime}$ end of $\mathrm{SHI} 000$ ysx C & This study \\
\hline pELC4 & pETBlue-I-based ysx C $\mathrm{His}_{6}$ tag translational fusion & This study \\
\hline pELC6 & Tet-T-P $\mathrm{P}_{\text {spac }}$ cassette upstream ysx C gene in pGL4II & This study \\
\hline $\begin{array}{l}\text { pETBlue-I } \\
\text { AccepTor }\end{array}$ & 3'-dA overhang cloning plasmid vector for protein overexpression; ColEI ori & Novagen \\
\hline pGL400 & Tet-T-P spac $_{\text {cassette }}$ & This study \\
\hline pGL4II & $\mathrm{POB}$ derivative containing $\mathrm{SHI} 000 \mathrm{ys} x \mathrm{C}$ and flanking regions & This study \\
\hline pGL433 & TAP-tag-kan cassette & This study \\
\hline pGL485 & pMJ8426-based lacl pEI94ori cat & This study \\
\hline PMAL7 & Kanamycin resistance gene (kan) & [6I] \\
\hline PMJ8426 & lacl pEI94ori & [26] \\
\hline $\mathrm{POB}$ & Erythromycin/lincomycin resistance gene (ery); ColEI ori & {$[54]$} \\
\hline
\end{tabular}

$\operatorname{det}(\mathrm{NP} 40)$ at a final concentration of $1.5 \%(\mathrm{v} / \mathrm{v})$. Protein A-bound complexes were excised from the resin by TEV protease cleavage, performed by addition of $1 \mathrm{ml}$ of TEV cleavage buffer and 100 units of AcTEV protease (Invitrogen). The beads were rotated for $16 \mathrm{~h}$ at $4{ }^{\circ} \mathrm{C}$. The TEV cleavage eluate containing the protein complex CBP-YsxC -protein partners was recovered by gravity flow and $1 \mathrm{ml}$ was mixed with $3 \mathrm{ml}$ of Calmodulin Binding Buffer (10 $\mathrm{mM}$ Tris-HCl $\mathrm{pH}$ 8.0, $10 \mathrm{mM}$ 2-mercaptoethanol, 150 $\mathrm{mM} \mathrm{NaCl}, 1 \mathrm{mM}$ magnesium acetate, $1 \mathrm{mM}$ imidazole, 2 $\mathrm{mM} \mathrm{CaCl}_{2}, 0.1 \% \mathrm{v} / \mathrm{v}$ Nonidet NP-40) and $3 \mu \mathrm{l} 1 \mathrm{M} \mathrm{CaCl}_{2}$. The resulting solution was applied to a column containing $200 \mu \mathrm{l}$ of Calmodulin-Sepharose beads (Stratagene) that had been washed with $10 \mathrm{ml}$ of Calmodulin Binding Buffer. The column was then rotated for $1 \mathrm{~h}$ at $4^{\circ} \mathrm{C}$. Elution was performed by gravity flow and the beads washed three times with $10 \mathrm{ml}$ Calmodulin Binding Buffer. The bound proteins were eluted with Calmodulin Elution Buffer (10 mM Tris-HCl pH 8.0, $10 \mathrm{mM}$ 2-mercaptoethanol, $150 \mathrm{mM} \mathrm{NaCl}, 1 \mathrm{mM}$ magnesium acetate, $1 \mathrm{mM}$ imidazole, $2 \mathrm{mM}$ EGTA, $0.1 \% \mathrm{v} / \mathrm{v}$ Nonidet NP-40) in $10 \times 200$ $\mu \mathrm{l}$ fractions. Proteins purifed as described from the equiv- alent of $15 \mathrm{l}$ of original culture were TCA precipitated and separated using a gradient of $4-12 \%(w / v)$ SDS-PAGE and silver stained. Two independent and equivalent experiments were undertaken Distinctive bands were in-gel tryptic digested, and prepared for positive-ion MALDI mass spectra (Applied Byosystems 4700 Proteomics Analyzer), MS spectra were acquired, and the strongest peaks with a signal to noise greater than 40 were selected for CID-MS/ MS analysis (Technology Facility, University of York). Mass spectral data were submitted to database searching using the MASCOT program (Matrix Science Ltd.) The Mowse scoring algorithm uses empirically determined factors to assign a statistical weight to each individual peptide match. The threshold level indicates that a match is significant if it would be expected to occur at random with a frequency of less than $5 \%$. Therefore, individual ions with scores greater than the calculated threshold level indicate identity or extensive homology.

\section{Subcellular localisation}

S. aureus $\mathrm{SH} 1000$ (2 1 culture) was grown to an $\mathrm{OD}_{600} \sim 3$ and immediately transferred to an ice slurry for $10 \mathrm{~min}$. 
Table 3: Oligonucleotide primers used in this study

\begin{tabular}{|c|c|}
\hline Primer & Sequence (5' $\left.\varnothing 3^{\prime}\right)$ \\
\hline 5'GLUSh3I & ataaGGATCCtggcctgtttaataggatct ${ }^{\prime}$ \\
\hline 3'GLUSh3I & ataaGGATCCaacttgtagcaggaagtggt $\mathrm{t}^{\prime}$ \\
\hline 3'GLUSh6A & taaatAAGCTTaattgtgagcggctcacaattccac' \\
\hline 5'GLUSh6Al & tattaaGCGGCCGCtcattgcttccaaggagctaaagaggtccctag ${ }^{\prime}$ \\
\hline 3'GLUSh6B & atattAAGCTTagaaatccctttgagaatgttt $\mid$ \\
\hline 5'GLUSh6BI & tattaaGCGGCCGCcggattttatgaccgatgatgaag 1 \\
\hline 5'GLUShI6H & attaattcaatattattaggattaactttcattttatatcctcacttaattgtgagcggctcacaattccac ${ }^{2}$ \\
\hline 3'GLUShI6H & ttcaaatattatataatggtagagttgaaagagaatataaaattagaaatccctttgagaatgtt ${ }^{2}$ \\
\hline 5'GLUSh65B & cttacattatttttaaaatttttgtataagttttgtcgtacaaaaaatcgatacaaattcctcg2 2 \\
\hline 3'GLUSh65B & ataataaacaacaacaaatatggaatttaattgaaccgtatatttcaatggaaaagagaagatgg² \\
\hline 5'GLUSh27A & aattgGGCGCGCCatggaaaagagaagatgg $\mid$ \\
\hline 3'GLUSh27A & atttGCGGCCGCtcaggttgacttccccgcgg \\
\hline 5'GLUSh27B & atttGCGGCCGCgataaacccagcgaaccattg $\mid$ \\
\hline 3'GLUSh27B & atttGGCCGGCCatcgatacaaattcctcg' \\
\hline 5'GLUSh I03A & taatgtATCGATaataatggtttcttagacgI \\
\hline 3'GLUShI03A & tattatGTCGACagtcggcattatctc ${ }^{\prime}$ \\
\hline 5'elc4 & atgaaagttaatcctaataatattg \\
\hline 3'elc4 & ttacaccaccaccaccaccactgaaatatacggttcaattaaattc ${ }^{3}$ \\
\hline
\end{tabular}

I upper case bases indicate restriction sites engineered within the oligonucleotide

2 italics indicate the fragment of the oligonucleotide designed for $\lambda_{\text {red }}$ recombination, whilst non-italics indicate the portion of the primer designed to amplify the insert; blackboxes indicate the location of the RBS and the START of ysxC in the complementary strand (5'GLUSh I6H) or the $3^{\prime}$ end of the ysxC sequence (3'GLUSh65B).

3 for $3^{\prime}-d A$ overhang ligation

Cells were harvested $\left(6,000 \mathrm{rpm}, 10 \mathrm{~min}, 4^{\circ} \mathrm{C}\right)$, broken using a Braun homogeniser, and the membrane/ribosome fraction purified by ultracentrifugation at 50,000 rpm for $2.5 \mathrm{~h}$ in a $70.1 \mathrm{Ti}$ rotor (Beckman). The resulting pellet was resuspended in $7 \mathrm{ml}$ of $0.01 \mathrm{M}$ Tris- $\mathrm{HCl} \mathrm{pH} \mathrm{8.2,} 14$ $\mathrm{mM}$ magnesium acetate, $60 \mathrm{mM}$ potassium acetate, $1 \mathrm{mM}$ DTT containing $0.5 \%(\mathrm{v} / \mathrm{v})$ Triton X-100 to solubilise membranes. The ultracentrifugation step was repeated and the pellet resuspended in $6 \mathrm{ml}$ of the above buffer containing $1 \mathrm{M} \mathrm{NH}_{4} \mathrm{Cl}$. The sample was ultracentrifuged again and the resulting pellet was resuspended in $5 \mathrm{ml}$ of the above buffer.

\section{YsxC overexpression, purification and production of antisera}

A His(6)tagged version of YsxC was constructed by cloning the $y s x C$ gene PCR-amplified from S. aureus SH1000 (using primers 5'elc4 and 3'elc4, and ReadyMix, ABgene) into the 3'-dA overhang site of the overexpression vector pETBlue-1 AccepTor vector (Novagen). The resulting plasmid (pELC4) was subsequently electroporated into E. coli TunerTM (DE3) pLacI (Novagen). Cells were grown in LB $50 \mu \mathrm{g} \mathrm{ml}^{-1} \mathrm{Amp}$ on a rotary shaker $(250 \mathrm{rpm})$ at $37^{\circ} \mathrm{C}$ to an $\mathrm{OD}_{600}=0.5$. Then expression was induced by the addition of $0.5 \mathrm{mM}$ IPTG and further incubation undertaken for $3 \mathrm{hrs}$. Cells were harvested by centrifugation at 5,500 rpm for $10 \mathrm{~min}$ (Jouan CR3i rotor AC50.10), and the pellet was stored at $-20^{\circ} \mathrm{C}$. The pellet was resuspended in 20 $\mathrm{ml}$ of Buffer C (50 mM Tris-HCl pH 8.0). Cells were dis- rupted by sonication (Sanyo MSE Soniprep 150; 16 micron amplitude, $2 \times 20 \mathrm{sec}$ treatments). Inclusion bodies were recovered by centrifugation at $10,000 \mathrm{rpm}$ in a Beckman JA-20 rotor for $10 \mathrm{~min}$ and were subsequently washed three times via resuspension in $10 \mathrm{ml}$ of buffer $\mathrm{C}$, $10 \mathrm{ml}$ buffer $\mathrm{C}$ plus $1 \mathrm{M} \mathrm{NaCl}$, and $10 \mathrm{ml}$ buffer $\mathrm{C}$, and centrifugation. Each time pellets were suspended in the buffer and then collected by centrifugation at 10,000 rpm for 5 min (Beckman JA-20 rotor). Washed inclusion bodies were suspended in $20 \mathrm{ml}$ of buffer C plus $8 \mathrm{M}$ Urea, left to dissolve for $20 \mathrm{~min}$ with stirring and then remaining insoluble material was removed by centrifugation in a Beckman JA-20 rotor at $19,000 \mathrm{rpm}$ for $15 \mathrm{~min}$ at $4^{\circ} \mathrm{C}$. The sample was applied on a $12 \mathrm{ml} \mathrm{Ni-column} \mathrm{(imino-}$ diacetic acid as a chelator immobilized on Sepharose 6B $\mathrm{FF}$, Sigma). The column was washed with $25 \mathrm{ml}$ of $8 \mathrm{M}$ Urea in buffer $\mathrm{C}$, then with $25 \mathrm{ml} 8 \mathrm{M}$ urea in $50 \mathrm{mM} 2$ (N-morpholino)ethane sulphonic acid (MES)/ $\mathrm{NaOH}$ buffer pH 6.3 and finally with $25 \mathrm{ml}$ of $8 \mathrm{M}$ Urea in 50 $\mathrm{mM}$ sodium acetate buffer $\mathrm{pH}$ 4.6. The $\mathrm{pH} 6.3$ wash contained the recombinant protein and was concentrated using a VivaSpin concentrator 100000 MWCO (Viva Science). Samples were applied on a Hi-Load Superdex 200 $16 \times 60 \mathrm{~cm}$ (Amersham) equilibrated with $6 \mathrm{M}$ Urea in buffer C. Proteins were eluted from the column in the same buffer and $2 \mathrm{ml}$ fractions were collected and analysed for protein content. The resulting protein was dialysed against PBS. $1 \mathrm{mg}$ of the purified protein was then 
used for production of polyclonal antibodies against YsxC (Antibody Resource Centre, University of Sheffield).

\section{Sucrose gradient centrifugation}

SH1000 and LC109 (SH1000 $\mathrm{P}_{\text {spac }} \sim \gamma s x C /$ pGL485) inoculated to an starting OD600 0.01 and grown to an $\mathrm{OD}_{600} \sim 0.5$ in BHI and BHI plus $20 \mu \mathrm{g} \mathrm{ml}^{-1}$ Cam, respectively. Growth of LC109 in the absence of IPTG results in noticeable but partial YsxC depletion. After breakage with a Braun homogeniser, cell extracts were centrifuged at $50,000 \mathrm{rpm}$ for $2.5 \mathrm{~h}$ in a Beckman $70.1 \mathrm{Ti}$ rotor at $4{ }^{\circ} \mathrm{C}$. The supernatant was removed and the pellet resuspended in $2 \mathrm{ml}$ of either S buffer [20] or Ribosome buffer [19]. Both buffers were supplemented with protease inhibitors (Complete, Roche; 1 tablet in $25 \mathrm{ml}$ and added at a 1:25 dilution to the reaction mixture). $30 \mathrm{ml} 10-30 \%$ (w/v) sucrose gradients were formed using a Hoefer gradient maker. Samples corresponding to $2 \mathrm{l}$ of original culture were layered on top of the gradient and centrifuged at $19,000 \mathrm{rpm}$ for $16 \mathrm{~h}$ at $4^{\circ} \mathrm{C}$ in a Beckman SW28 rotor. 1 $\mathrm{ml}$ fractions were removed from the base of the gradient and RNA levels were assayed by diluting each sample 1:100 in Tris-HCl pH 7.8 and measuring absorbance at $260 \mathrm{~nm}$.

\section{List of Abbreviations}

TAP: tandem affinity purification; CBP: calmodulin binding protein.

\section{Authors' contributions}

ELC, JGL and SJF contributed in the design of the study and in the writing of the manuscript. ELC and JGL carried out the genetic constructs necessary for the work and the determinations of $y s x C$ essentiality. ELC performed the purification of YsxC partners, its subcellular localization, and its association with the ribosome. All authors read and approved manuscript.

\section{Acknowledgements}

We would like to thank Chia Y. Lee for kindly providing plasmid pMJ8426. TAP plasmid PSBI479 was obtained from Euroscarf http://web.uni-frank furt.de/fb / $5 /$ mikro/euroscarf/ord tpla.html. This work was supported by the Biotechnology and Biological Sciences Research Council (United Kingdom).

\section{References}

I. Shopsin B, Mathema B, Martinez J, Ha E, Campo ML, Fierman A, Krasinski K, Kornblum J, Alcabes P, Waddington M, et al.: Prevalence of methicillin-resistant and methicillin-susceptible Staphylococcus aureus in the community. J Infect Dis 2000, 182:359-362.

2. National Nosocomial Infections Surveillance (NNIS) System Report, data summary from January 1992 through June 2004, issued October 2004. Am J Infect Control 2004, 32:470-485.

3. Tiemersma EW, Bronzwaer SL, Lyytikainen O, Degener JE, Schrijnemakers P, Bruinsma N, Monen J, Witte W, Grundman H: Methicillin-resistant Staphylococcus aureus in Europe, 1999-2002. Emerg Infect Dis 2004, 10:1627-1634.

4. Zetola N, Francis JS, Nuermberger EL, Bishai WR: Communityacquired meticillin-resistant Staphylococcus aureus: an emerging threat. Lancet Infect Dis 2005, 5:275-286.
5. Hutchison CA, Peterson SN, Gill SR, Cline RT, White O, Fraser CM, Smith HO, Venter JC: Global transposon mutagenesis and a minimal Mycoplasma genome. Science 1999, 286:2165-2169.

6. Kobayashi K, Ehrlich SD, Albertini A, Amati G, Andersen KK, Arnaud M, Asai K, Ashikaga S, Aymerich S, Bessieres P, et al: Essential Bacillus subtilis genes. Proc Natl Acad Sci USA 2003, 100:4678-4683.

7. Caldon CE, March PE: Function of the universally conserved bacterial GTPases. Curr Opin Microbiol 2003, 6:135-I39.

8. Comartin DJ, Brown ED: Non-ribosomal factors in ribosome subunit assembly are emerging targets for new antibacterial drugs. Curr Opin Pharmacol 2006, 6:453-458.

9. Schaefer L, Uicker WC, Wicker-Planquart C, Foucher AE, Jault JM, Britton RA: Multiple GTPases participate in the assembly of the large ribosomal subunit in Bacillus subtilis. J Bacteriol 2006, I 88:8252-8258.

10. Wicker-Planquart $C$, Foucher AE, Louwagie M, Britton RA, Jault JM: Interactions of an essential Bacillus subtilis GTPase, YsxC, with ribosomes. J Bacteriol 2007, 190:68I-690.

II. Campbell TL, Daigle DM, Brown ED: Characterization of the Bacillus subtilis GTPase YloQ and its role in ribosome function. Biochem J 2005, 389:843-852.

12. Datta K, Skidmore JM, Pu K, Maddock JR: The Caulobacter crescentus GTPase CgtAC is required for progression through the cell cycle and for maintaining $\mathbf{5 0} \mathrm{S}$ ribosomal subunit levels. Mol Microbiol 2004, 54:1379-1392.

13. Matsuo Y, Morimoto T, Kuwano M, Loh PC, Oshima T, Ogasawara $\mathrm{N}$ : The GTP-binding protein YlqF participates in the late step of $\mathbf{5 0} \mathrm{S}$ ribosomal subunit assembly in Bacillus subtilis. J Biol Chem 2006, 28 I :8 I I0-8 I I 7.

14. Sato A, Kobayashi G, Hayashi H, Yoshida H, Wada A, Maeda M, Hiraga S, Takeyasu K, Wada C: The GTP binding protein Obg homolog ObgE is involved in ribosome maturation. Genes Cells 2005, 10:393-408.

15. Uicker WC, Schaefer L, Koenigsknecht M, Britton RA: The essential GTPase YqeH is required for proper ribosome assembly in Bacillus subtilis. J Bacteriol 2007, 189:2926-2929.

16. Dassain M, Leroy A, Colosetti L, Carole S, Bouche JP: A new essential gene of the 'minimal genome' affecting cell division. Biochimie 1999, 81:889-895.

17. Pragai Z, Harwood CR: YsxC, a putative GTP-binding protein essential for growth of Bacillus subtilis 168. J Bacteriol 2000, 182:6819-6823.

18. Ruzheinikov SN, Das SK, Sedelnikova SE, Baker PJ, Artymiuk PJ, Garcia-Lara J, Foster SJ, Rice DW: Analysis of the open and closed conformations of the GTP-binding protein YsxC from Bacillus subtilis. J Mol Biol 2004, 339:265-278.

19. Blaha G, Stelzl U, Spahn CM, Agrawal RK, Frank J, Nierhaus KH: Preparation of functional ribosomal complexes and effect of buffer conditions on tRNA positions observed by cryoelectron microscopy. Methods Enzymol 2000, 3 17:292-309.

20. Champney WS, Burdine R: Macrolide antibiotics inhibit $50 \mathrm{~S}$ ribosomal subunit assembly in Bacillus subtilis and Staphylococcus aureus. Antimicrob Agents Chemother 1995, 39:2 I4I-2 I44.

21. Jana M, Luong TT, Komatsuzawa H, Shigeta M, Lee CY: A method for demonstrating gene essentiality in Staphylococcus aureus. Plasmid 2000, 44: 100-104.

22. Sobral RG, Ludovice AM, de Lencastre H, Tomasz A: Role of murF in cell wall biosynthesis: isolation and characterization of a murF conditional mutant of Staphylococcus aureus. J Bacteriol 2006, 188:2543-2553.

23. Zheng L, Yang J, Landwehr C, Fan F, Ji Y: Identification of an essential glycoprotease in Staphylococcus aureus. FEMS Microbiol Lett 2005, 245:279-285.

24. Dubrac S, Msadek T: Identification of genes controlled by the essential YycG/YycF two-component system of Staphylococcus aureus. J Bacteriol 2004, 186: 1 175- 1181 .

25. Forsyth RA, Haselbeck RJ, Ohlsen KL, Yamamoto RT, Xu H, Trawick JD, Wall D, Wang L, Brown-Driver V, Froelich JM, et al.: A genomewide strategy for the identification of essential genes in Staphylococcus aureus. Mol Microbiol 2002, 43:1387-1400.

26. Galperin MY, Koonin EV: 'Conserved hypothetical' proteins: prioritization of targets for experimental study. Nucleic Acids Res 2004, 32:5452-5463.

27. Puig O, Caspary F, Rigaut G, Rutz B, Bouveret E, Bragado-Nilsson E, Wilm M, Seraphin B: The tandem affinity purification (TAP) 
method: a general procedure of protein complex purification. Methods 200I, 24:218-229.

28. Butland G, Peregrin-Alvarez JM, Li J, Yang W, Yang X, Canadien V, Starostine A, Richards D, Beattie B, Krogan N, et al.: Interaction network containing conserved and essential protein complexes in Escherichia coli. Nature 2005, 433:53I-537.

29. Estevez AM, Kempf T, Clayton C: The exosome of Trypanosoma brucei. Embo J 200I, 20:383I-3839.

30. Rohila JS, Chen M, Cerny R, Fromm ME: Improved tandem affinity purification tag and methods for isolation of protein heterocomplexes from plants. Plant $J$ 2004, 38: I72-I8I.

31. Westermarck J, Weiss C, Saffrich R, Kast J, Musti AM, Wessely M, Ansorge W, Seraphin B, Wilm M, Valdez BC, Bohmann D: The DEXD/H-box RNA helicase RHII/Gu is a co-factor for c-Junactivated transcription. Embo / 2002, 2I:45I-460.

32. Held WA, Ballou B, Mizushima S, Nomura M: Assembly mapping of $30 \mathrm{~S}$ ribosomal proteins from Escherichia coli. Furthe studies. I Biol Chem 1974, 249:3 I03-3 III.

33. Homann HE, Nierhaus KH: Ribosomal proteins. Protein compositions of biosynthetic precursors and artifical subparticles from ribosomal subunits in Escherichia coli K I2. Eur J Biochem 1971, 20:249-257.

34. Marquardt $\mathrm{O}$, Roth HE, Wystup G, Nierhaus $\mathrm{KH}$ : Binding of Escherichia coli ribosomal proteins to 23 S RNA under reconstitution conditions for the $\mathbf{5 0}$ S subunit. Nucleic Acids Res 1979 6:364|-3650.

35. Stoffler-Meilicke M, Noah M, Stoffler G: Location of eight ribosomal proteins on the surface of the $50 \mathrm{~S}$ subunit from Escherichia coli. Proc Natl Acad Sci USA 1983, 80:6780-6784.

36. Zouine M, Beloin C, Ghelis C, Le Hegarat F: The LI7 ribosomal protein of Bacillus subtilis binds preferentially to curved DNA. Biochimie 2000, 82:85-91.

37. Sharrock RA, Leighton T: Intergenic suppressors of temperature-sensitive sporulation in Bacillus subtilis are allele nonspecific. Mol Gen Genet 198I, I 83:532-537.

38. Morimoto T, Loh PC, Hirai T, Asai K, Kobayashi K, Moriya S, Ogasawara N: Six GTP-binding proteins of the Era/Obg family are essential for cell growth in Bacillus subtilis. Microbiology 2002, I 48:3539-3552.

39. Kobayashi G, Moriya S, Wada C: Deficiency of essential GTPbinding protein ObgE in Escherichia coli inhibits chromosome partition. Mol Microbiol 200 I, 4I:1037-I05I.

40. Minkovsky N, Zarimani A, Chary VK, Johnstone BH, Powell BS, Torrance PD, Court DL, Simons RW, Piggot PJ: Bex, the Bacillus subtilis homolog of the essential Escherichia coli GTPase Era, is required for normal cell division and spore formation. J Bacteriol 2002, 184:6389-6394.

4I. Diaconu M, Kothe U, Schlunzen F, Fischer N, Harms JM, Tonevitsky AG, Stark H, Rodnina MV, Wahl MC: Structural basis for the function of the ribosomal L7/I2 stalk in factor binding and GTPase activation. Cell 2005, I 2 I:99|-1004.

42. Moore PB: The three-dimensional structure of the ribosome and its components. Annu Rev Biophys Biomol Struct 1998, 27:35-58.

43. Chandra Sanyal S, Liljas A: The end of the beginning: structural studies of ribosomal proteins. Curr Opin Struct Biol 2000 10:633-636.

44. Agafonov DE, Kolb VA, Spirin AS: Proteins on ribosome surface: measurements of protein exposure by hot tritium bombardment technique. Proc Natl Acad Sci USA 1997, 94: I 2892-I 2897.

45. Zouine M, Beloin C, Deneubourg AM, Hirschbein L, Le Hegarat F Overproduction, purification and characterization of the HPB I 2-L24 ribosomal protein of Bacillus subtilis. FEMS Microbiol Lett 1996, | 45:4|-48.

46. Daigle DM, Brown ED: Studies of the interaction of Escherichia coli YjeQ with the ribosome in vitro. J Bacteriol 2004, 186: $|38|-\mid 387$

47. Sayed A, Matsuyama S, Inouye M: Era, an essential Escherichia coli small G-protein, binds to the $30 \mathrm{~S}$ ribosomal subunit. Biochem Biophys Res Commun 1999, 264:5I-54.

48. Scott JM, Ju J, Mitchell T, Haldenwang WG: The Bacillus subtilis GTP binding protein obg and regulators of the sigma(B) stress response transcription factor cofractionate with ribosomes. J Bacteriol 2000, 182:277 I-2777.

49. Sharma MR, Barat C. Wilson DN, Booth TM, Kawazoe M, Hori-Takemoto C, Shirouzu M, Yokoyama S, Fucini P, Agrawal RK: Interaction of Era with the $30 \mathrm{~S}$ ribosomal subunit implications for $30 \mathrm{~S}$ subunit assembly. Mol Cell 2005, I8:319-329.

50. Trahey M, McCormick F: A cytoplasmic protein stimulates normal N-ras p2I GTPase, but does not affect oncogenic mutants. Science 1987, 238:542-545.

5I. Lin B, Covalle KL, Maddock JR: The Caulobacter crescentus CgtA protein displays unusual guanine nucleotide binding and exchange properties. J Bacteriol 1999, 181:5825-5832.

52. Jiang M, Datta K, Walker A, Strahler J, Bagamasbad P, Andrews PC Maddock JR: The Escherichia coli GTPase CgtAE is involved in late steps of large ribosome assembly. J Bacteriol 2006, I 88:6757-6770.

53. Sikora $A E$, Zielke R, Datta K, Maddock JR: The Vibrio harveyi GTPase CgtAV is essential and is associated with the $50 \mathrm{~S}$ ribosomal subunit. J Bacteriol 2006, I88: I205-I2I0.

54. Horsburgh MJ, Wharton SJ, Cox AG, Ingham E, Peacock S, Foster SJ: MntR modulates expression of the PerR regulon and superoxide resistance in Staphylococcus aureus through control of manganese uptake. Mol Microbiol 2002, 44: I269-I 286.

55. Guerout-Fleury AM, Shazand K, Frandsen N, Stragier P: Antibioticresistance cassettes for Bacillus subtilis. Gene 1995, 167:335-336.

56. Vagner V, Dervyn E, Ehrlich SD: A vector for systematic gene inactivation in Bacillus subtilis. Microbiology 1998, I44(Pt II):3097-3I04.

57. Lee EC, Yu D, Martinez de Velasco J, Tessarollo L, Swing DA, Court DL, Jenkins NA, Copeland NG: A highly efficient Escherichia colibased chromosome engineering system adapted for recombinogenic targeting and subcloning of BAC DNA. Genomics 200I, 73:56-65.

58. Kreiswirth BN, Lofdahl S, Betley MJ, O'Reilly M, Schlievert PM, Bergdoll MS, Novick RP: The toxic shock syndrome exotoxin structural gene is not detectably transmitted by a prophage. Nature 1983, 305:709-7|2.

59. Novick RP: Genetic systems in staphylococci. Methods Enzymol 1991, 204:587-636.

60. Grkovic S, Brown MH, Hardie KM, Firth N, Skurray RA: Stable lowcopy-number Staphylococcus aureus shuttle vectors. Microbiology 2003, I 49:785-794.

6I. Horsburgh MJ, Clements MO, Crossley H, Ingham E, Foster SJ: PerR controls oxidative stress resistance and iron storage proteins and is required for virulence in Staphylococcus aureus. Infect Immun 2001, 69:3744-3754.

62. Hartleib J, Kohler N, Dickinson RB, Chhatwal GS, Sixma JJ, Hartford OM, Foster T], Peters G, Kehrel BE, Herrmann M: Protein A is the von Willebrand factor binding protein on Staphylococcus aureus. Blood 2000, 96:2149-2।56.

63. Horsburgh MJ, Aish JL, White IJ, Shaw L, Lithgow JK, Foster SJ: sigmaB modulates virulence determinant expression and stress resistance: characterization of a functional rsbU strain derived from Staphylococcus aureus 8325-4. J Bacteriol 2002, 184:5457-5467.

Publish with Biomed Central and every scientist can read your work free of charge

"BioMed Central will be the most significant development for disseminating the results of biomedical research in our lifetime. "

Sir Paul Nurse, Cancer Research UK

Your research papers will be:

- available free of charge to the entire biomedical community

- peer reviewed and published immediately upon acceptance

- cited in PubMed and archived on PubMed Central

- yours - you keep the copyright
BioMedcentral 